\title{
Active dry Saccharomyces cerevisiae can alleviate the effect of subacute ruminal acidosis in lactating dairy cows
}

\author{
O. AlZahal, ${ }^{*}$ L. Dionissopoulos, ${ }^{*}$ A. H. Laarman, ${ }^{*}$ N. Walker, $\dagger$ and B. W. McBride ${ }^{* 1}$ \\ *Department of Animal and Poultry Science, University of Guelph, Guelph, N1G 2W1, Canada \\ †AB Vista, Marlborough, Wiltshire SN8 4AN, United Kingdom
}

\section{ABSTRACT}

The objective of the study was to determine the effect of active dry Saccharomyces cerevisiae (ADSC) supplementation on dry matter intake, milk yield, milk components, ruminal $\mathrm{pH}$, and microbial community during a dietary regimen that leads to subacute ruminal acidosis (SARA). Sixteen multiparous, rumen-cannulated lactating Holstein cows were randomly assigned to 1 of 2 dietary treatments that included ADSC (Biomate; AB Vista, Marlborough, UK; $8 \times 10^{10} \mathrm{cfu} /$ head per day) or control. During wk 1 to 6 , all cows received a high-forage (HF) diet (77:23, forage:concentrate). Cows were then abruptly switched during wk 7 to a high-grain (HG) diet (49:51, forage:concentrate) and remained on the HG until the end of wk 10. Feed intake and milk yields were recorded daily. Ruminal $\mathrm{pH}$ was recorded continuously using an indwelling system for 1 to $2 \mathrm{~d}$ per week during the pre-experimental phase, and wk 6, 7, and 10. Ruminal digesta samples were collected at the end of the experiment and analyzed for relative change in microbial communities using realtime quantitative PCR. Cows were considered to have SARA if the duration below $\mathrm{pH} 5.6$ was $\geq 300 \mathrm{~min} / \mathrm{d}$. Ruminal pH during wk 6 (HF plateau) was not different across treatments $(15 \pm 46 \mathrm{~min} / \mathrm{d}$ at $\mathrm{pH}<5.6)$. The dietary regimen successfully induced SARA during wk 7 (transition from $\mathrm{HF}$ to $\mathrm{HG}$ diet), and ruminal $\mathrm{pH}(551 \pm 46 \mathrm{~min} / \mathrm{d}$ at $\mathrm{pH}<5.6)$ was not different across treatments. However, cows receiving ADSC had an improved ruminal $\mathrm{pH}(122 \pm 57$ vs. $321 \pm 53 \mathrm{~min} / \mathrm{d}$ at $\mathrm{pH}<5.6$ ) during wk 10 (HG plateau) compared with control. Additionally, cows receiving ADSC had a better dry matter intake $(23.3 \pm 0.66$ vs. $21.6 \pm 0.61 \mathrm{~kg} / \mathrm{d})$ and $4 \%$ fat-corrected milk yield $(29.6 \pm 1.2$ vs. $26.5 \pm$ $1.2 \mathrm{~kg} / \mathrm{d}$ ) than control cows during the HG phase (wk 8 to 10). During HG feeding, cows receiving ADSC had greater total volatile fatty acid and propionate concen-

Received April 7, 2014.

Accepted August 28, 2014.

${ }^{1}$ Corresponding author: bmcbride@uoguelph.ca trations (175 \pm 7.5 vs. $154 \pm 7.5$ and $117 \pm 6.1$ vs. $94 \pm$ $5.7 \mathrm{~m} M$ for ADSC and control, respectively) and lower acetate:propionate ratio $(0.26 \pm 0.5$ vs. $0.36 \pm 0.05$ for ADSC and control, respectively). Microbial analyses conducted on samples collected during wk 10 showed that cows supplemented with $S$. cerevisiae had a 9-fold, 2 -fold, 6 -fold, 1.3-fold, and 8-fold increase in S. cerevisiae, Fibrobacter succinogenes, Anaerovibrio lipolytica, Ruminococcus albus, and anaerobic fungi, respectively, which suggested an increase in cellulolytic microbes within the rumen. Cows supplemented with ADSC had 2.2-fold reduction in Prevotella albensis, which is a gram-negative bacterium predominant during SARA. Prevotella spp. are suggested to be an important source of lipopolysaccharide responsible for inflammation within the rumen. Cows supplemented with ADSC had a 2.3-fold increase in Streptococcus bovis and a 12-fold reduction in Megasphaera elsdenii. The reduction in $M$. elsdenii may reflect lower concentration of lactic acid within the rumen for ADSC cows. In conclusion, ADSC supplementation to dairy cows was demonstrated to alleviate the condition of SARA caused by abrupt dietary changes from $\mathrm{HF}$ to $\mathrm{HG}$, and can potentially improve rumen function, as indicated by greater numbers of cellulolytic microorganisms within the rumen.

Key words: Saccharomyces cerevisiae, subacute ruminal acidosis, rumen microbes, dairy cattle

\section{INTRODUCTION}

Subacute ruminal acidosis is a common digestive disorder in dairy cows caused by feeding rapidly fermentable carbohydrates. The condition is characterized by a diurnal depression in ruminal $\mathrm{pH}$ due to the accumulation of VFA, and to a lesser extent lactic acid, within the rumen (Oetzel, 2000). A research model using cannulated dairy cows has defined SARA as a decline in ruminal $\mathrm{pH}$ below 5.6 for approximately 300 $\mathrm{min} / \mathrm{d}$ (AlZahal et al., 2007a). Symptoms of SARA are variable, but often include depressed intake, resulting in poor body condition and reduced production (Plaizier et al., 2008), and may predispose cows to milk fat depression (AlZahal et al., 2009, 2010). 
Ruminant nutritionists have used a spectrum of feed additives to improve ruminal $\mathrm{pH}$ and maximize fiber degradation, namely by directly feeding active dry bacteria and yeast and yeast culture products. Active dry yeast products are manufactured in a manner to maintain a specific number of live cells $\left(>1.5 \times 10^{10} \mathrm{cfu} / \mathrm{g}\right.$ of DM), thus preserving the majority of the products' ability to ferment forages.

The mechanisms proposed to explain the mode of action of active dry yeast within the rumen are mainly focused on optimizing fiber digestion [see review by Chaucheyras-Durand et al. (2008)]. Active dry yeast was proposed to survive for a short period of time within the rumen by utilizing traces of dissolved oxygen, which can be directly involved in fiber digestion and (or) can create an optimal anaerobic environment for bacterial growth. Live yeast was also proposed to create optimal growth conditions for bacteria by preventing the accumulation of lactic acid within the rumen (Nocek, 1997). Most commercially available active dry yeasts are based on strains of Saccharomyces cerevisiae. Yeast culture products, on the other hand, do not contain a guaranteed live yeast cell level but rather yeast fermentation by-products. Those by-products have been suggested to affect the growth of ruminal microbes (Callaway and Martin, 1997).

Studies that examined the effects of active dry yeast, exclusively, on performance and digestive characteristics of lactating ruminants are scarce and inconclusive. It was reported that active dry yeast supplementation can increase DMI and milk yield in early-lactation dairy cows (Wohlt et al., 1991) and dairy goats (Stella et al., 2007), whereas others reported no difference in dairy cattle (Swartz et al., 1994; Chiquette, 1995; Kung et al., 1997; Soder and Holden, 1999). The main variations among studies are likely due to differences in manufacturing processes, dosages and strains, and production systems. Additionally, the majority of available reviews of the literature, both the qualitative and the quantitative, did not differentiate between active dry yeast and yeast culture products, which limited the reliability of the results of such reviews. Studies evaluating the effect of active dry yeast on fermentation characteristics, including $\mathrm{pH}$, are limited to in vitro methods, which were considered inappropriate for studying the effect of yeast on $\mathrm{pH}$ due to its high buffering capabilities (Carro et al., 1992).

To our knowledge, no studies exist in the literature that directly examined the effect of active dry $S$. cerevisiae (ADSC) on mitigating SARA by utilizing a nutritional SARA induction model, and concurrently assessed changes in ruminal microbes. Therefore, the objective of the current study was to determine the effect of $S$. cerevisiae supplementation on ruminal $\mathrm{pH}$, cow performance (DMI, milk yield, and milk components), and microbial community during a dietary regimen that leads to SARA.

\section{MATERIALS AND METHODS}

\section{Animals, Treatments, and Feeding}

Sixteen multiparous lactating Holstein cows (166 \pm 30 DIM) were used in a randomized complete block design. Cows were randomly assigned into 1 of 2 blocks ( $\mathrm{n}=8$ each) and then assigned to 1 of the 2 dietary treatments that included ADSC (Biomate; AB Vista, Marlborough, UK; strain 1242) or control. The layout of the experimental design and feeding regimen is depicted in Figure 1. The 2 blocks were conducted in a staggered manner with 1-wk difference to facilitate complex measurements. The daily allotments of ADSC were prepared weekly by mixing $4 \mathrm{~g}$ of the ADSC product $\left(2 \times 10^{10} \mathrm{cfu} / \mathrm{g}\right.$ of DM) with $250 \mathrm{~g}$ of ground dry corn. The control diet contained the carrier only. Before starting the experiment, cows were maintained on a regular lactating-cow TMR fed twice daily (0700 and $1300 \mathrm{~h}$ ) that consisted (DM basis) of $28 \%$ corn silage, $27 \%$ haylage, $6 \%$ straw, $20 \%$ high-moisture corn, and $19 \%$ protein supplement. The TMR included approximately $16 \%$ CP, $40 \%$ NFC, and $33 \%$ NDF. During the first $6 \mathrm{wk}$, all cows received a high-forage $(\mathbf{H F})$ diet (Table 1). The HF diet was created by replacing $42 \%$ of the TMR (DM basis) with chopped hay. During wk 7 , cows were switched abruptly to a high-grain (HG) diet (Table 1), and cows remained on the HG diet until the end of wk 10. The HG diet was created by replacing $20 \%$ of the TMR (DM basis) with wheat and barley pellets (1:1). Cows were allowed only $1 \mathrm{~d}$ of transition from the HF to the HG diet, where they received only $50 \%$ of the grain pellet allotment. The HF diet, transition diet, and HG diet were remixed in a Data Ranger (American Calan Inc., Northwood, NH) and fed twice daily as a TMR. The HG diet has been reported in previous studies to induce sustainable SARA [see, for example, AlZahal et al. (2009)], whereas the HF has been designed to induce optimal ruminal conditions. Cows were top-dressed during the morning feeding (wk 1 through 10) with either the ADSC or control diet. The amount of offered feed was adjusted daily to allow a maximum of $5 \mathrm{~kg}$ of orts/d (as-fed basis). Researchers and technical staff were blinded to the treatments. Ingredients and chemical analyses of TMR are presented in Table 1.

The cows were housed in a tie-stall facility at the Ponsonby Dairy Research Station (University of Guelph, Guelph, ON, Canada). All experimental procedures were approved by the University of Guelph 


\begin{tabular}{|c|c|c|c|c|c|c|c|c|c|c|c|}
\hline Week & Time 0 & week 1 & week 2 & week 3 & week 4 & week 5 & week 6 & week 7 & week 8 & week 9 & week 10 \\
\hline Day & 1 & 4 & & & & $3 6 \longdiv { 3 8 }$ & & 5051 & & & $7172 \sqrt{2}$ \\
\hline $\mathrm{n}=8$ & TMR & \multicolumn{7}{|c|}{ High-forage + Control } & \multicolumn{3}{|c|}{ High-grain + Control } \\
\hline $\mathrm{n}=7$ & TMR & \multicolumn{6}{|c|}{ High-forage + ADSC } & & \multicolumn{3}{|c|}{ High-grain $+\mathrm{ADSC}$} \\
\hline
\end{tabular}

Figure 1. Layout of the experimental design and feeding regimen. Prior to the start of the experiment, cows received no added yeast and were maintained on regular TMR. Days 1 to 3 were used as a baseline measurement. The experiment commenced on d 4 and ended on d 73 . Cows were supplemented with either control (carrier only; $\mathrm{n}=8$ ) or active dry Saccharomyces cerevisiae (ADSC; $8 \times 10^{10} \mathrm{cfu} / \mathrm{head}$ per day; $\mathrm{n}=7$ ) starting on $\mathrm{d} 4$ and through d 73 . On d 4 through 49, cows were fed the high-forage diet. On d 50, cows were transitioned to the high-grain diet by feeding only $50 \%$ of the allotted amount of grain. On d 51 and through d 73, cows were fed the high-grain diet to induce SARA. Ruminal pH was measured on days shaded in black. Ruminal digesta were assessed on days shaded in gray for VFA (d 38 and 73) and for microbial analysis (d 73).

Animal Care Committee (animal utilization protocol no. 12R050) in accordance with the Canadian Council on Animal Care (CCAC, 1993).

\section{DMI, Feed Analysis, Milk Production, and Milk Components}

Offered TMR, orts, and milk yield were recorded daily for individual cows starting $3 \mathrm{~d}$ before the start of the experiment [to obtain baseline measurements while on the regular TMR (time 0); Figure 1] and throughout the experiment (10 wk). Samples from TMR (HF and HG) and orts were collected 3 times per week and frozen at $-20^{\circ} \mathrm{C}$ until analysis. The TMR and orts samples were dried for $48 \mathrm{~h}$ in a forced-air oven at $60^{\circ} \mathrm{C}$ to determine DM content for that week. Subsamples of TMR were pooled every 2 wk and analyzed (Agri-Food Laboratories Inc., Guelph, ON, Canada) for CP, ash, ether extract, NDF (Mertens, 1997), ADF [procedures 4.2.08, 4.1.10, 4.5.01, and 4.6.03, respectively (AOAC International, 1996)], soluble CP (Licitra et al., 1996), and starch concentration (Hall, 2000). The chemical analyses of TMR are presented in Table 1 . Cows were milked twice daily at 0500 and $1500 \mathrm{~h}$, and milk samples were collected 3

Table 1. Ingredient composition and chemical analyses of high-forage (HF) and high-grain (HG) diets

\begin{tabular}{|c|c|c|}
\hline \multirow[b]{2}{*}{ Item } & \multicolumn{2}{|c|}{ Diet } \\
\hline & $\mathrm{HF}$ & $\mathrm{HG}$ \\
\hline \multicolumn{3}{|l|}{ Ingredient, $\%$ of DM } \\
\hline Corn silage & 16.0 & 22.0 \\
\hline Alfalfa silage & 16.0 & 22.0 \\
\hline Straw & 3.6 & 4.9 \\
\hline High-moisture corn & 11.7 & 16.0 \\
\hline Protein supplement $^{1}$ & 11.0 & 15.1 \\
\hline Hay & 41.7 & 0.0 \\
\hline Grain pellets ${ }^{2}$ & 0.0 & 20.0 \\
\hline \multicolumn{3}{|c|}{ Chemical composition, \% of DM (unless otherwise noted) } \\
\hline DM, \% & 59.0 & 48.2 \\
\hline $\mathrm{CP}(\mathrm{N} \times 6.25)$ & 14.3 & 16.4 \\
\hline Soluble protein & 6.4 & 5.3 \\
\hline ADIN & 1.7 & 1.2 \\
\hline $\mathrm{ADF}$ & 32.5 & 18.4 \\
\hline NDF & 44.9 & 28.2 \\
\hline $\mathrm{NFC}^{3}$ & 31.5 & 45.2 \\
\hline Starch $^{4}$ & 16.6 & 26.2 \\
\hline Ether extract & 2.3 & 3.4 \\
\hline Ash & 7.0 & 6.9 \\
\hline $\mathrm{NE}_{\mathrm{L}},{ }^{5} \mathrm{Mcal} / \mathrm{kg}$ & 1.4 & 1.6 \\
\hline
\end{tabular}

${ }^{1}$ Supplement contained (as-fed basis) 9\% high-protein corn gluten meal, 30\% soybean meal 48 (containing $48 \%$ CP), $7 \%$ Tri-Pro Gold (Tri-County Protein Corp., Winchester, ON, Canada), $14 \%$ canola meal, $10 \%$ beat pulp, $3 \%$ herring meal, $4 \%$ dry corn distillers grains, $12 \%$ mineral mix, $5 \%$ soybean hulls, $2 \%$ molasses, and $3 \%$ tallow.

${ }^{2}$ Contained 2:1 wheat and barley.

${ }^{3} \mathrm{NFC}=100-(\mathrm{NDF}+\mathrm{CP}+$ ether extract + ash $)$.

${ }^{4}$ Analyzed according to Hall (2000).

${ }^{5}$ Estimated according to NRC (2001). 
times per week from morning and afternoon milkings. Milk samples were pooled by cow by day based on production, before being pooled by week using equal daily proportions, and submitted to Laboratory Services Division (Guelph, ON, Canada) for composition analysis using a near-infrared analyzer (Foss System 4000; Foss Electric A/S, Hillerød, Denmark).

\section{Ruminal pH, Ruminal VFA, and Ruminal Digesta}

Ruminal $\mathrm{pH}$ was measured and recorded continuously (1-min intervals) using a cordless indwelling $\mathrm{pH}$ electrode as described by AlZahal et al. (2007b). Briefly, a $\mathrm{pH}$ electrode was inserted through the cannula and connected to a data logger for data acquisition. The electrodes were attached a $0.5-\mathrm{kg}$ stainless steel weight to ensure that they resided in the ventral sac of the rumen. The data were downloaded daily for $\mathrm{pH}$ evaluation and analysis. Ruminal $\mathrm{pH}$ was recorded on $\mathrm{d} 1$ (regular TMR), d 36 (HF diet), d 50 (transition to the HG diet), d 51 (first day on the HG diet), and d 71 and 72 (on the HG diet).

Digesta grabs were collected from the ventral rumen at $1600 \mathrm{~h}$ on $\mathrm{d} 73$ and filtered through 4 layers of cheesecloth into duplicate 50-mL screw-top tubes. The first allotment was snap-frozen in liquid nitrogen and stored at $-20^{\circ} \mathrm{C}$ for VFA analysis. The concentration of VFA in ruminal digesta was quantified in duplicate using gas chromatography (Mutsvangwa et al., 2002). The second allotment was diluted 1:1 with $100 \%$ ethanol for microbial genomic DNA isolation.

\section{Microbial DNA Isolation, Quality Assessment, and Real-Time Quantitative PCR}

Approximately $1.5 \mathrm{~mL}$ of the ethanol-preserved rumen digesta samples were centrifuged at 12,000 $\times$ $g$ for $5 \mathrm{~min}$ at room temperature to create a pellet $(\sim 200 \mu \mathrm{g})$. The microbial DNA was isolated from the rumen digesta pellet according to $\mathrm{Yu}$ and Morrison (2004). The protocol included three 1-min rounds of bead-beating (Mini-bead-beater-8; BioSpec Products Inc., Bartlesville, OK) for mechanical disruption of microbial cells. The beating was conducted at room temperature and at maximum speed with the inclusion of $0.4 \mathrm{~g}$ of zirconium beads $(0.3 \mathrm{~g}$ of $0.1-\mathrm{mm}+0.1 \mathrm{~g}$ of $0.5-\mathrm{mm}$ beads). The quality of total DNA extracted from digesta samples was assessed by $0.8 \%$ agarose gel electrophoresis and total DNA concentration was quantified using a NanoDrop spectrophotometer (ND-1000; NanoDrop Technologies Inc., Wilmington, DE).

The PCR primers used to amplify microbial $16 \mathrm{~S}$ ribosomal DNA are listed in Table 2. The primers were assembled from the literature and tested for specificity in silico. The primers that did not meet our criteria for selection were redesigned using Primer Express 3.0 software (Applied Biosystems Inc., Foster City, CA). The primers were synthesized by Sigma (The Woodlands, TX). Real-time PCR was carried out using an AB 7300 system (Applied Biosystems Inc.). Each reaction mixture was run in duplicate. Amplification reactions were carried out with Power SYBR green PCR master mix (Applied Biosystems Inc.) mixed with the selected primer set (Table 2).

Changes in targeted populations (fold changes) were calculated using a relative quantification calculation and the $2^{-\Delta \Delta \mathrm{C}_{\mathrm{t}}}$ method (Livak and Schmittgen, 2001), with general bacteria (Denman and McSweeney, 2006) cycle threshold $\left(\mathrm{C}_{\mathrm{t}}\right)$ values used as the reference and average $\Delta \mathrm{C}_{\mathrm{t}}$ of the control group as the calibrator value.

\section{Statistical Analysis}

Weekly average of DMI, milk yield, and milk components were analyzed using PROC MIXED of SAS (SAS Institute, 2011), using a model that included treatment (ADSC or control), time (wk $1, \ldots, 10)$, treatment $\times$ time interaction, block ( 1 or 2 ), and treatment $\times$ block interaction as fixed effects. Measurements collected during time 0 (average of $\mathrm{d} 1$ to 3 ) were used as a covariate. Week was used as a repeated measurement with cow as the subject. For each analyzed variable, cow was subjected to 5 covariance structures: compound symmetry, heterogeneous compound symmetry, autoregressive order $1[\mathbf{A R}(\mathbf{1})]$, heterogeneous autoregressive order 1, and unstructured covariance structure. The covariance that gave the smallest Bayesian information criterion (BIC) was used (Littell et al., 1996). Compound symmetry gave the smallest BIC values for milk component content and yield, whereas AR(1) gave smallest values for DMI and milk yield.

Ruminal $\mathrm{pH}$ data were downloaded from individual loggers and the time $(\mathrm{min} / \mathrm{d})$ below a $\mathrm{pH}$ threshold of $5.6(<5.6)$ during any given day $\times$ cow was counted. The same model was used to analyze $\mathrm{pH}$ data on $\mathrm{d} 36$ (HF diet), d 50 (transition to the HG diet), d 51(first day on the HF diet), and average of d 71 and 72 (SARA plateau). The covariate consisted of d 1 measurement (on regular TMR; Figure 1). The covariance AR(1) gave the smallest $\mathrm{BIC}$ values and was used.

Orthogonal polynomial contrasts were used to compare means of treatment (ADSC vs. control) for DMI, milk yield and components, and ruminal $\mathrm{pH}$ within each dietary phase (HF, HG, or transition where applicable).

The PROC TTEST (SAS) was used to test whether mean ruminal $\mathrm{pH}<5.6(\mathrm{~min} / \mathrm{d})$ of a given group was different from 0 and $\geq 300 \mathrm{~min} / \mathrm{d}$ (for example, 300, 
Table 2. Primers used for real-time PCR quantification

\begin{tabular}{|c|c|c|c|c|c|}
\hline Target organism & Primer & Sequence $\left(5^{\prime} \rightarrow 3^{\prime}\right)$ & $\operatorname{Tm}$ & $\begin{array}{l}\text { Amplicon } \\
\text { size, bp }\end{array}$ & Source of primer \\
\hline \multirow{2}{*}{ General bacteria } & 1114 & CGGCAACGAGCGCAACCC & 60 & 130 & Denman and McSweeney (2006) \\
\hline & 1275 & CCATTGTAGCACGTGTGTAGCC & 60 & & \\
\hline \multirow[t]{2}{*}{ General anaerobic fungi } & Fungi_F & GAGGAAGTAAAAGTCGTAACAAGGTTTC & 60 & 120 & \\
\hline & Fungi_R & CAAATTCACAAAGGGTAGGATGATT & 60 & & \\
\hline \multirow[t]{2}{*}{ Ciliate protozoa } & P-SSU-316f & GCTTTCGWTGGTAGTGTATT & 55 & 223 & Sylvester et al. (2004) \\
\hline & p-SSU-539r & ACTTGCCCTCYAATCGTWCT & 55 & & \\
\hline \multirow[t]{2}{*}{ Yeast (Saccharomyces cerevisiae) } & Yeast_F & ACAGACACAGAGCCCGAACAT & 60 & 72 & This study ${ }^{1}$ \\
\hline & Yeast_R & TGCCCAGAGGGAGTATTCACA & 60 & & \\
\hline \multirow{2}{*}{ Anaerovibrio lipolytica } & AnaLip2F & TGGGTGTTAGAAATGGATTCTAGTG & 56.6 & 109 & Khafipour et al. (2009) \\
\hline & AnaLip2R & GCACGTCATTCGGTATTAGCAT & 57.7 & & \\
\hline \multirow{2}{*}{ Butyrivibrio fibrisolvens } & BfiBF & ACACACCGCCCGTCACA & 55 & 64 & Klieve et al. (2003) \\
\hline & BfiBR & TCCTTACGGTTGGGTCACAGA & 55 & & \\
\hline \multirow{2}{*}{ Escherichia coli } & EcoliFimH2F & GCCGGTGGCGCTTTATTTG & 57.3 & 114 & Khafipour et al. (2009) \\
\hline & EcoliFimH2R & TCATCGCTGTTATAGTTGTTGGTCT & 58.4 & & \\
\hline \multirow[t]{2}{*}{ Fibrobacter succinogenes } & FibSuc4F & GGAGCGTAGGCGGAGATTCA & 58.7 & 97 & \\
\hline & FibSuc4R & GCCTGCCCCTGAACTATCCA & 58.5 & & \\
\hline \multirow[t]{2}{*}{ Lactobacillus spp. } & Ulac16S1F & AGCAGTAGGGAATCTTCCA & 51.5 & 345 & Lan et al. (2004) \\
\hline & Ulac16S1R & ATTCCACCGCTACACATG & 51.1 & & \\
\hline \multirow{2}{*}{ Megasphaera elsdenii } & MegEls1F & GACCGAAACTGCGATGCTAGA & 57.7 & 129 & Ozutsumi et al. (2006) \\
\hline & MegEls1R & CGCCTCAGCGTCAGTTGTC & 58.2 & & \\
\hline \multirow[t]{2}{*}{ Prevotella albensis } & ProAlb4F & GCGCCACTGACGCTGAAG & 58.3 & 110 & Khafipour et al. (2009) \\
\hline & ProAlb4R & CCCCAAATCCAAAAGGACTCAG & 56.6 & & \\
\hline \multirow[t]{2}{*}{ Prevotella brevis } & PreBre2F & GCGAACTGGTTTCCTTGAGTGTATT & 58.8 & 153 & \\
\hline & PreBre2R & ACCTTCGAGCTTTAGCGTCAGTTAT & 57.6 & & \\
\hline \multirow{2}{*}{ Prevotella bryantii } & ProBry4F & GAAGGCAGCTCGCTGTAGTGTT & 60.6 & 145 & \\
\hline & ProBryR & CTTAACGCTTTCGCTTAGCCACT & 59.4 & & \\
\hline \multirow[t]{2}{*}{ Ruminococcus albus } & RumAlb1F & CCCTAAAAGCAGTCTTAGTTCG & 54.3 & 176 & \\
\hline & RumAlb1R & CCTCCTTGCGGTTAGAACA & 53.8 & & \\
\hline \multirow{2}{*}{ Ruminococcus flavefaciens } & RF_new_F & CGAACGGAGATAATTTGAGTTTACTTAGG & 60 & 132 & Denman and McSweeney (2006) \\
\hline & $R F \_n e w \_R$ & CGGTCTCTGTATGTTATGAGGTATTACC & 60 & & \\
\hline \multirow[t]{2}{*}{ Selenomonas ruminantium } & SelRum2F & CAATAAGCATTCCGCCTGGG & 61 & 71 & Stevenson and Weimer (2007) \\
\hline & SelRum2R & TTCACTCAATGTCAAGCCCTGG & 61 & & \\
\hline \multirow{2}{*}{ Streptococcus bovis } & StrBov2F & TTCCTAGAGATAGGAAGTTTCTTCGG & 59 & 82 & \\
\hline & StrBov2R & ATGATGGCAACTAACAAT AGGGGT & 59 & & \\
\hline \multirow[t]{2}{*}{ Succinimonas amylolytica } & SucAmy2F & CGTTGGGCGGTCATTTGAAAC & 55.2 & 139 & Khafipour et al. (2009) \\
\hline & SucAmy2R & CCTGAGCGTCAGTTACTATCCAGA & 56.2 & & \\
\hline \multirow[t]{2}{*}{ Succinivibrio dextrinosolvens } & SucDex1F & CGTCAGCTCGTGTCGTGAGA & 60 & 80 & Stevenson et al. (2007) \\
\hline & SucDex1R & CCCGCTGGCAACAAAGG & 60 & & \\
\hline
\end{tabular}

을 ${ }^{1}$ Designed based on National Center for Biotechnology Information (NCBI) accession no. Y08934 adopted from (Castillo-Lopez et al., 2010) using Primer Express 3.0 software (Applied Biosystems Inc., Foster City, CA) 
$400, \ldots, \mathrm{n} \mathrm{min} / \mathrm{d}$ ). A given treatment group was considered as having SARA if ruminal $\mathrm{pH}<5.6(\mathrm{~min} / \mathrm{d})$ was different from 0 but not different from $\geq 300 \mathrm{~min} / \mathrm{d}$ and vice versa.

Ruminal VFA data were analyzed using POC MIXED of SAS, the model included treatment (ADSC or control), time (d 38 and 73 on the HF and HG diet, respectively), block, and their interactions as fixed effects. Orthogonal polynomial contrasts were used to separate the means. The PROC TTEST of SAS was used to test if the relative fold change in the concentration of individual microbial $16 \mathrm{~S}$ ribosomal DNA was significant from 0 (no change due ADSC). Data were logarithmically $\left(\log _{2}\right)$ transformed before analysis.

\section{RESULTS}

\section{Ruminal $\mathrm{pH}$}

Ruminal $\mathrm{pH}$ was assessed during time 0 (on regular TMR), wk 5 (HF), and wk 11 (HG; Figure 1). Ruminal $\mathrm{pH}$ measurement during time 0 was used as a covariate in the analysis, and also was used to exclude any individual cow with preexisting SARA. This criteria was used to comply with our objective, which was to examine the effect of ADSC supplementation during SARA induction. Cows were considered to have SARA if the duration below $\mathrm{pH} 5.6$ was $\geq 300$ $\mathrm{min} / \mathrm{d}$ (AlZahal et al., 2007a). One cow in the ADSC group (cow no. 3641) was deemed to have preexisting SARA and was removed from the trial. Ruminal $\mathrm{pH}$ (min/d <5.6; Figure 2) during wk 6 (HF plateau) was not different across treatments and both treatment groups were not different from $0 \mathrm{~min} / \mathrm{d}$ but different from $\geq 300 \mathrm{~min} / \mathrm{d}(P<0.001)$, which indicated that both treatment groups did not have SARA. The dietary regimen successfully induced SARA during wk 7 (transition from the HF to HG diet) in both treatment groups $(\mathrm{pH}<5.6$ were not different from $\geq 300$ $\mathrm{min} / \mathrm{d})$. Additionally, ruminal $\mathrm{pH}(\mathrm{min} / \mathrm{d}<5.6)$ was not different across treatments. The dietary model to induce SARA has been used successfully in previous studies (AlZahal et al., 2009, 2010) and has been shown to induce sustainable depression in ruminal $\mathrm{pH}$ without causing a drastic impairment of rumen function or intake. Furthermore, after 3 wk of HG feeding (wk 10), cows receiving ADSC had higher ruminal $\mathrm{pH}$ compared with controls (122 \pm 57 vs. $321 \pm 53 \mathrm{~min} / \mathrm{d}$ $<5.6$, respectively; $P=0.01)$. Cows supplemented with ADSC were considered to have recovered from SARA within $3 \mathrm{wk}(\mathrm{pH}<5.6$ not different from $0 \mathrm{~min} / \mathrm{d}$ but different from $\geq 300 \mathrm{~min} / \mathrm{d} ; P=0.02$ ); whereas cows receiving the control diet did not recover from SARA
( $\mathrm{pH}<5.6$ not different from $\geq 300 \mathrm{~min} / \mathrm{d}$ but different from $0 \mathrm{~min} / \mathrm{d} ; P<0.001)$.

\section{DMI, Milk Yield, and Milk Components}

During HF feeding (wk 1 through 6), average weekly DMI (Figure 3a) and milk yield and parameters (Table 3) did not differ across treatments, with the exception of lactose content, as cows receiving ADSC had a slightly greater $(P=0.04)$ lactose content compared with controls. Nonetheless, lactose yield $(\mathrm{kg} / \mathrm{d})$ did not differ across treatments. During the transition week to HG (SARA induction week), milk yield and parameters were not different across treatments and, similarly to the previous phase, lactose content was greater $(P=$ 0.01) in cows receiving ADSC compared with controls (Table 3). However, during wk 7, cows that received the control diet had lower DMI (Figure 3a; $P=0.01$ ). During the HG feeding phase (wk 8, 9, and 10), cows receiving the control diet continued to have lower $(P=$ 0.03) DMI (kg/d; Figure 3a). The observed difference in intake was reflected by a reduction in fat yield $(\mathrm{kg} / \mathrm{d}$; Table $3 ; P=0.01)$ and $4 \% \mathrm{FCM}(\mathrm{kg} / \mathrm{d}$; Figure $3 \mathrm{~b} ; P$ $=0.03)$. No difference was detected in other measured milk parameters.

\section{Ruminal VFA}

The concentration of ruminal VFA was assessed during wk 5 and 10. No difference across treatments were detected during HF feeding in total VFA $(115 \pm 7.5$ vs. $107 \pm 7.5 \mathrm{~m} M$ for the ADSC and control diet, respectively) and most measured VFA (m $M$; Figure 4), with the exception of butyrate and the acetate:propionate $(\mathbf{A}: \mathbf{P})$ ratio, as cows receiving ADSC had greater butyrate concentration (mM; Figure $4 ; P=0.04)$ and a smaller A:P ratio $(0.88 \pm 0.5$ vs. $1.09 \pm 0.05$ for ADSC and control diet, respectively; $P=0.01$ ) compared with controls. The shift to HG increased the concentration $(\mathrm{m} M)$ of total VFA $(P<0.001$; data shown below $)$ and also increased the concentration $(\mathrm{m} M)$ of propionate $(P$ $<0.001)$, butyrate $(P=0.001)$, valerate $(P<0.001)$, and isovalerate $(P=0.01)$, and reduced the concentration of acetate $(P<0.001$; Figure 4$)$. However, the change with HG feeding was more pronounced for cows receiving ADSC on total VFA $(175 \pm 7.5$ vs. $154 \pm$ $7.5 \mathrm{~m} M$ for the ADSC and control diet, respectively) and propionate concentration (mM; Figure 4). Furthermore, the A:P ratio was reduced $(P<0.001)$ with $\mathrm{HG}$ feeding and cows receiving ADSC maintained a significantly smaller A:P ratio $(0.26 \pm 0.5$ vs. $1.36 \pm 0.05$ for the ADSC and control diet, respectively). The HG feeding significantly reduced the concentration $(\mathrm{m} M)$ 


\section{Day/diet}

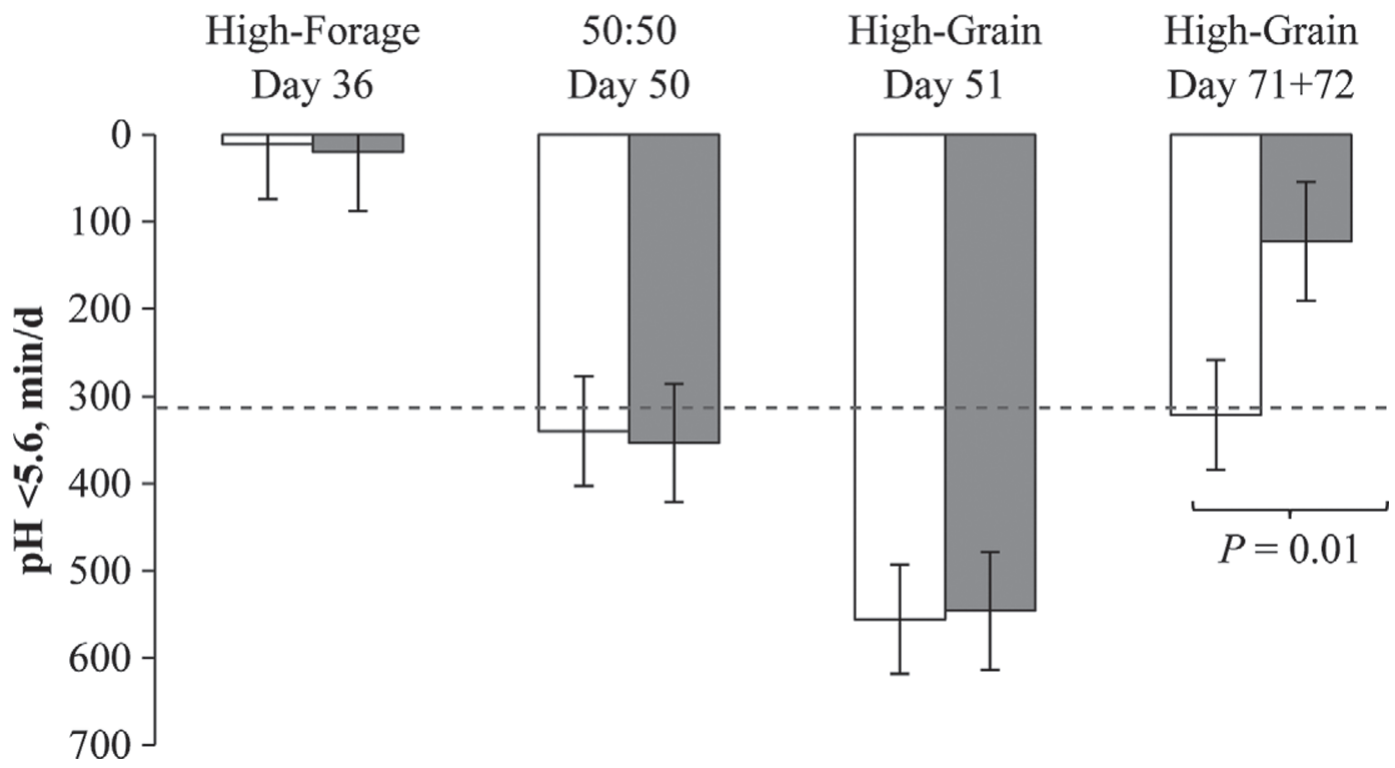

Figure 2. Least squares means of ruminal $\mathrm{pH}$ (time below 5.6; min/d) during high-forage feeding, transition (50:50), and high-grain feeding. Cows were either supplemented with control (carrier only; $\mathrm{n}=8$; white bars) or active dry Saccharomyces cerevisiae $\left(8 \times 10^{10}\right.$ cfu/head per day; $\mathrm{n}=7$; gray bars). Cows were considered as having SARA when the $\mathrm{pH}$ exceeded $300 \mathrm{~min} / \mathrm{d}$ below 5.6 (dotted line). Error bars represent SE.

of isobutyrate only for those cows receiving the ADSC supplement (Figure 4).

\section{Ruminal Microbes}

Microbial analyses conducted on samples collected during wk 10 showed that cows supplemented with ADSC had a 9-fold difference in S. cerevisiae population $(P=0.003)$ compared with controls. Additionally, cows supplemented with ADSC had a 6-fold increase in Anaerovibrio lipolytica $(P=0.05)$ and a 2 -fold increase in Fibrobacter succinogenes $(P=0.03)$, and had a tendency for a 1.3-fold increase in Ruminococcus albus ( $P$ $=0.01)$ and an 8-fold increase in anaerobic fungi $(P$ $=0.09$ ) relative to controls. On the other hand, cows supplemented with ADSC had a 2.2-fold reduction in Prevotella albensis $(P=0.01)$. Cows supplemented with ADSC had a 2.3-fold increase in Streptococcus bovis ( $P$ $=0.05)$ and a tendency $(P=0.08)$ for a 12 -fold reduction in Megasphaera elsdenii.

\section{DISCUSSION}

We hypothesized that supplementing cows with ADSC would mitigate SARA. This mitigation was proposed to alleviate the effect of abrupt changes from the $\mathrm{HF}$ to $\mathrm{HG}$ diet on ruminal $\mathrm{pH}$, intake, and production. The experiment was designed to allow the cows to acclimatize to an $\mathrm{HF}$ diet and thus create optimum rumen conditions before inducing SARA. Cows were either supplemented with the ADSC or control diet while on the HF diet and before switching to HG to assess the ability of the treatment groups to withhold SARA. Ruminal $\mathrm{pH}$ measured during HF feeding did not decrease below 5.6 (Figure 2), which indicated that cows did not have SARA (AlZahal et al., 2007a). Dry matter intake and milk yield and parameters were similar between the treatment groups and were typical for mid-lactation Holstein cow (Table 3; Figure 1). Cows were abruptly changed from HF to HG to mimic field conditions where, in most of the cases, managerial errors or sudden dietary changes (i.e., postcalving) were to blame for causing SARA. We allowed only $1 \mathrm{~d}$ of transition to ensure that cows did not get severe depression in ruminal $\mathrm{pH}$ and (or) get off feed. The SARA induction regimen relied on feeding a TMR twice daily; however, this TMR contained a high proportion of grains (high-moisture corn, wheat, and barley pellets). This model has been shown in previous experiments to induce chronic SARA (AlZahal et al., 2009, 2010; Dionissopoulos et al., 2013). Ruminal pH measured on d 51 (first day on the HG diet; Figure 2) were decreased for over $500 \mathrm{~min} / \mathrm{d}$ to below 5.6 , with no differences between treatments. The first few days after dietary shifts are considered critical as cows attempt to cope with the new condition via several physiological processes, such as limiting intake to reduce ruminal acid load (Plaizier et al., 2008). However, although both treatments 


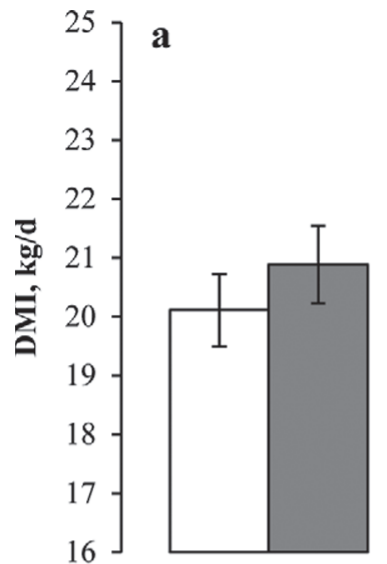

wk 1-6

High-Forage

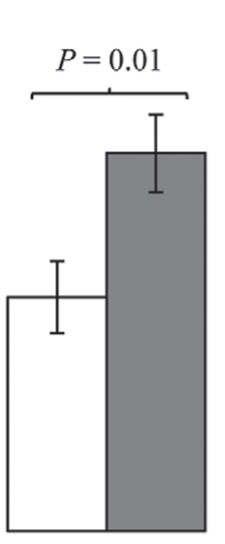

wk 7

50:50

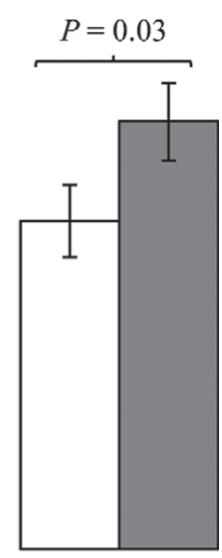

wk 8-10

High-Grain

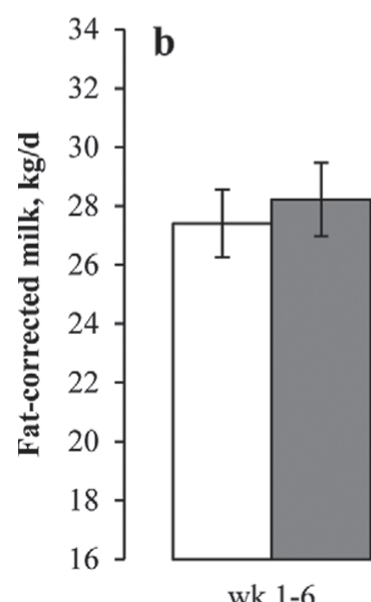

High-Forage

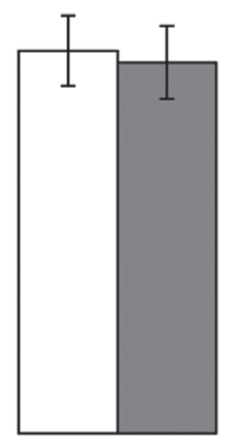

wk 7

50:50
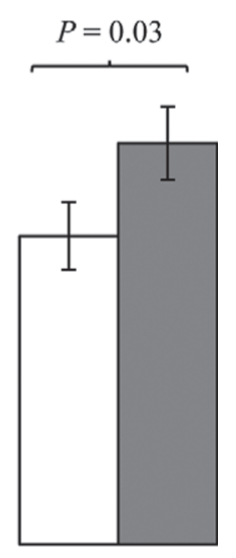

wk 8-10

High-Grain

\section{Week/diet}

Figure 3. Least squares means of DMI (a; $\mathrm{kg} / \mathrm{d})$ and $4 \% \mathrm{FCM}(\mathrm{b}$; $\mathrm{kg} / \mathrm{d}$ ) during high-forage feeding, transition week (50:50), and highgrain feeding. Cows were either supplemented with control (carrier only; $\mathrm{n}=8$; white bars $)$ or active dry Saccharomyces cerevisiae $(8 \times$ $10^{10} \mathrm{cfu} /$ head per day; $\mathrm{n}=7$; gray bars). Error bars represent SE.

groups had a depressed ruminal $\mathrm{pH}$ during the first week of HG feeding; cows receiving ADSC had greater intake, which may indicate that ADSC-supplemented sustained better rumen function. To fulfill the objective of this study, cows remained approximately for $3 \mathrm{wk}$ on the HG diet, and the cows' performance and ruminal parameters were assessed toward the end of the third week (plateau phase). Interestingly, results showed that cows supplemented with ADSC had a significantly higher $\mathrm{pH}$ compared with nonsupplemented cows. Ruminal $\mathrm{pH}$ of ADSC-supplemented cows, as measured by the duration of $\mathrm{pH}<5.6$, was not indicative of SARA, whereas nonsupplemented cows had a depressed ruminal $\mathrm{pH}$ indicative of SARA $(\geq 300 \mathrm{~min} / \mathrm{d}$ at $\mathrm{pH}<5.6$; AlZahal et al., 2007a). Our results were in agreement

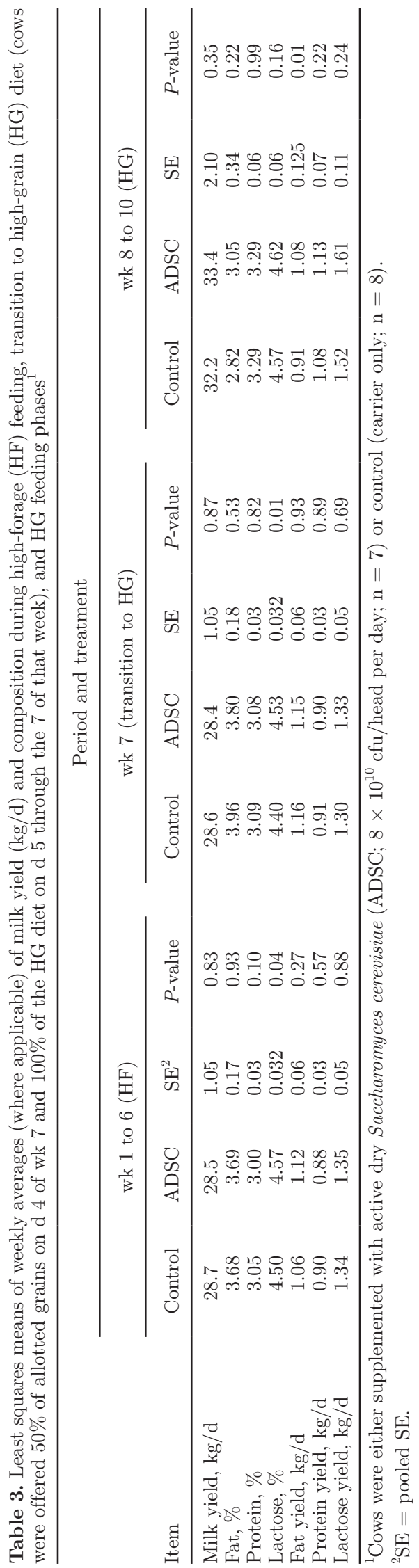

Journal of Dairy Science Vol. 97 No. 12, 2014 


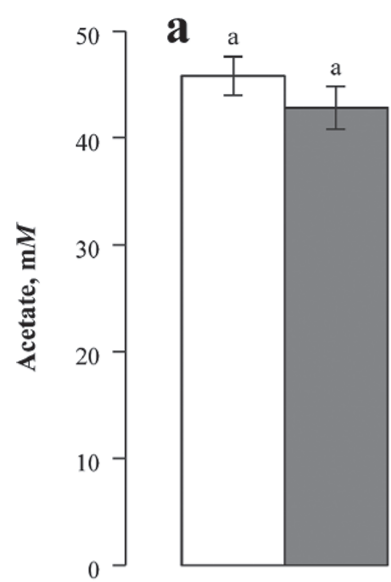

38

High-Forage

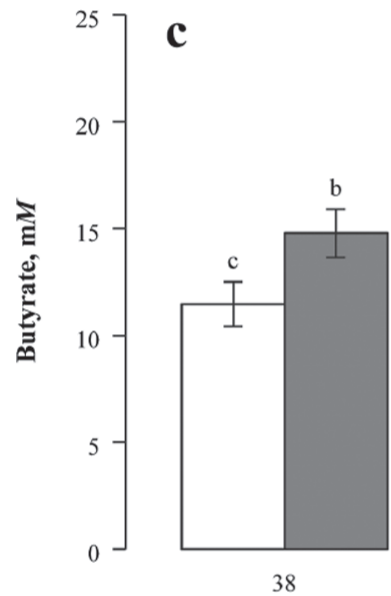

High-Forage

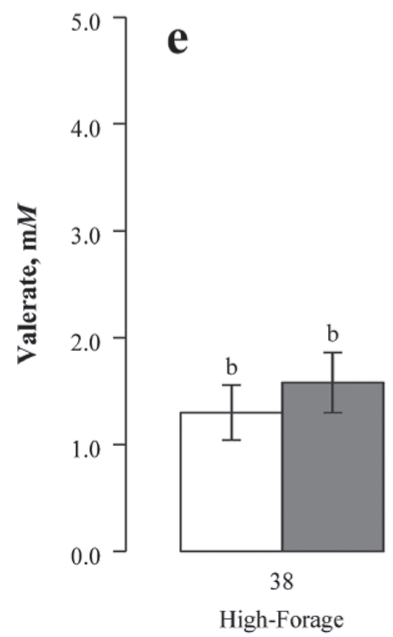

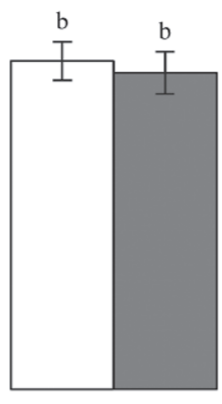

73

High-Grain

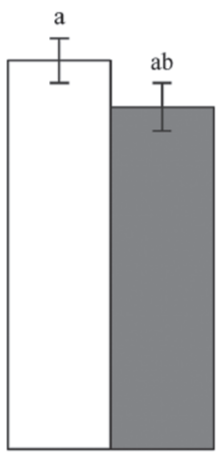

73

High-Grain

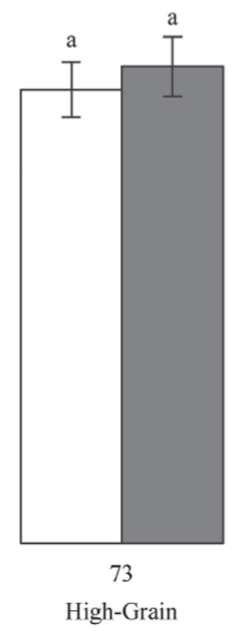

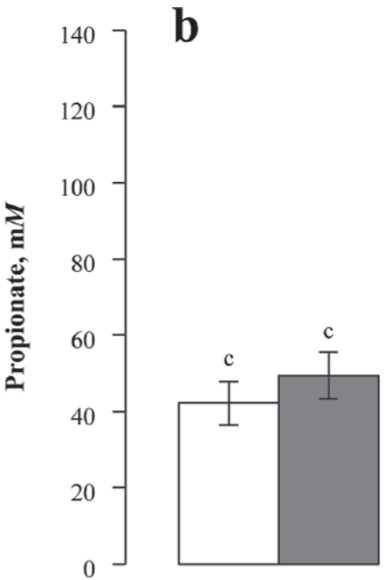

38

High-Forage

d

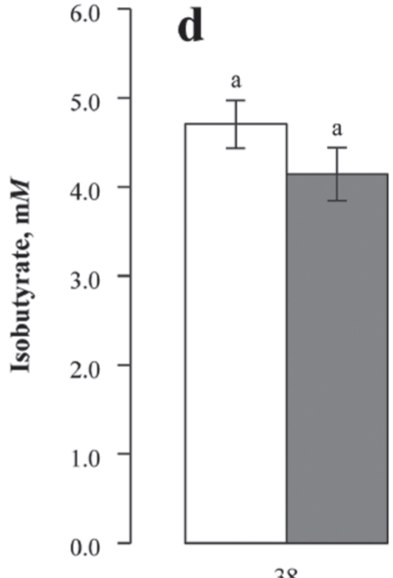

High-Forage

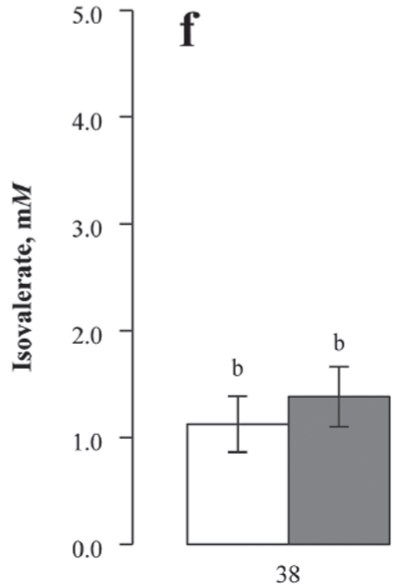

High-Forage
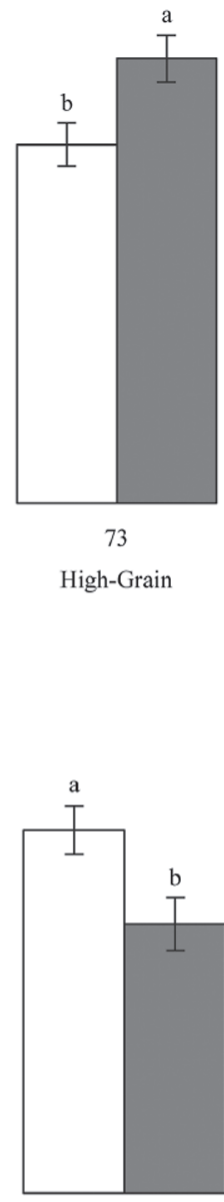

High-Grain

\section{Day/diet}

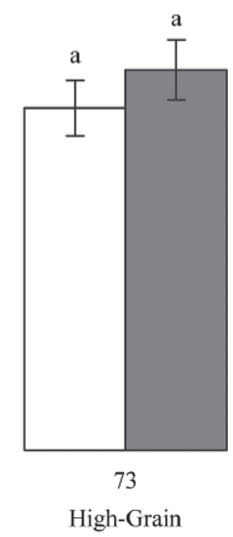

Day/diet

Figure 4. Rumen concentration $(\mathrm{m} M)$ of acetate (a), propionate (b), butyrate (c), isobutyrate (d), valerate (e), and isovalerate (f) during high-fiber (measured on d 38) and high-grain diet (measured on d 73) feeding. Cows were either supplemented with control (carrier only; $\mathrm{n}=$ 8; white bars) or active dry Saccharomyces cerevisiae $\left(8 \times 10^{10} \mathrm{cfu} /\right.$ head per day; $\mathrm{n}=7$; gray bars $)$. Bars labeled with different letters within a given chart are different $(P<0.05)$. Error bars represent SE. 
with Al-Ibrahim et al. (2012), who demonstrated that ADSC supplementation $\left(2.5 \times 10^{9} \mathrm{cfu} /\right.$ head per day) increased ruminal $\mathrm{pH}$ in cows when abruptly or gradually switched to pasture postcalving compared with nonsupplemented cows $(2.3$ vs. $3.5 \mathrm{~h}$ at $\mathrm{pH}<5.8$, respectively). Contrary to our results, Chung et al. (2011) tested 2 different strains of ADSC $\left(1 \times 10^{10} \mathrm{cfu} /\right.$ head per day) and reported that strain 1 had no effect on ruminal $\mathrm{pH}$, whereas strain 2 reduced ruminal $\mathrm{pH}$ compared with controls $(1.0,7.5$, and $3.3 \mathrm{~h} / \mathrm{d}$ at $\mathrm{pH}$ $<5.6$, respectively). However, variations in ruminal $\mathrm{pH}$ among studies may be attributed to the use of different sampling techniques (rumenocentesis and stomach tubing vs. cannulation), number of samples collected (few per day vs. continuous recoding every minute), or methodology of summarizing $\mathrm{pH}$ data (daily mean, minimum vs. duration below a given $\mathrm{pH}$ threshold). Nonetheless, it is well documented that using continuous recording of ruminal $\mathrm{pH}$ via an indwelling probe and summarizing ruminal $\mathrm{pH}$ as duration below 5.6 is the most reliable method to define ruminal $\mathrm{pH}$ (Plaizier et al., 2008).

The greater intake observed in the current study for ADSC-supplemented cows was sustained as the mean weekly average (wk 8 through 10) was significantly greater than for control cows. It is noticeable that the cows, in general, consumed significantly more feed while on HG compared with HF (week main effect), likely due to the higher fiber content in the HF diet (Table 1; Allen, 1997). The improved ruminal conditions and intake was associated, in the current study, with an increase in fat yield and 4\% FCM (Figure 3). The effect of ADSC on DMI and milk yield as was demonstrated in the Introduction section has been shown to be highly variable. Increased intake or diet fermentability can translate to greater OM available for ruminal fermentation and, thus, greater VFA concentration and lower ruminal $\mathrm{pH}$ within the rumen (Allen, 1997). In the current study, feeding HG increased total VFA concentration and consequently reduced ruminal $\mathrm{pH}$. However, cows supplemented with ADSC had less $\mathrm{pH}$ depression (Figure 2) than nonsupplemented cows despite their greater increase in total VFA concentration, suggesting an increase in ruminal buffering capacity (Giger-Reverdin et al., 2004) in ADSC-supplemented cows.

Several mechanisms have been proposed to explain the mode of action of live ADSC within the rumen. The most acceptable mechanism was optimizing fiber digestion through eliminating dissolved oxygen within the rumen and improving lactate metabolism (production and utilization), thus creating an optimal environment for cellulolytic microbes (Chaucheyras-Durand et al., 2008). Although the rumen environment is strictly anaerobic, Newbold (1995) reported that $16 \mathrm{~L} / \mathrm{d}$ can enter the rumen through feed and water consumption and salivation. In the current experiment, S. cerevisiae numbers were 9-fold greater relative to nonsupplemented cows (Figure 4), which confirms that S. cerevisiae can indeed proliferate within the rumen. This increase in S. cerevisiae was associated with an increase in bacterial species known to degrade fiber within the rumen, such as F. succinogenes, A. lipolytica, and $R$. albus. It has been shown that the activity and growth of 3 major cellulolytic bacteria (F. succinogenes, R. albus, and Ruminococcus flavefaciens) in the rumen of sheep were stimulated by ADSC supplementation (Fonty and Chaucheyras-Durand, 2006). This is in agreement with the current study, with the exception of $R$. flavefaciens. The current study showed no effect of ADSC supplementation on that bacterium. Additionally, the current results demonstrated an increase in anaerobic fungi with ADSC supplementation, which further supports the effect of ADSC supplementation in improving fiber degradation. However, the relationship between $S$. cerevisiae and anaerobic fungi growth has not been confirmed in vivo (Chaucheyras-Durand et al., 2008). The available literature on in vitro studies suggests that $A D S C$ can enhance the colonization of specific anaerobic fungal strains (Chaucheyras et al., 1995).

It was suggested that ADSC can improve rumen function and increase ruminal $\mathrm{pH}$ by increasing lactate utilization (Nocek, 1997). In vitro studies have reported that live ADSC can stimulate the growth of lactate-utilizing bacteria such as M. elsdenii and Selenomonas ruminantium and consequently reduce lactate concentration [see review by Chaucheyras-Durand et al. (2008)]. However, it was reported that the level of lactate within the rumen of dairy cattle plays little or no role in the etiology of SARA, given its low accumulation within the rumen (Plaizier et al., 2008). For example, Chung et al. (2011) induced acidosis in dairy cattle and reported that ruminal lactate concentration, on average, never exceeded $0.5 \mathrm{~m} M$ throughout the day. Lactate was not measured in the current study but the high variation in $M$. elsdenii bacteria observed among animals suggests that $M$. elsdenii was not affected by ADSC supplementation. A recent study by Pinloche et al. (2013) demonstrated that cows fed a diet that consisted of $61 \%$ corn silage and $39 \%$ concentrate (DM basis) and supplemented with either $\operatorname{ADSC}(0.5$ to $5 \times$ $10^{10} \mathrm{cfu} /$ head per day) had greater VFA concentration, higher $\mathrm{pH}$, and lower lactate compared with the control, and that those changes were associated with increased abundance of a main fibrolytic group (Fibrobacter and Ruminococcus) and, contrary to our results, lactate-utilizing bacteria (Megasphaera and Selenomonas). Those authors supported the hypothesis proposed to explain 


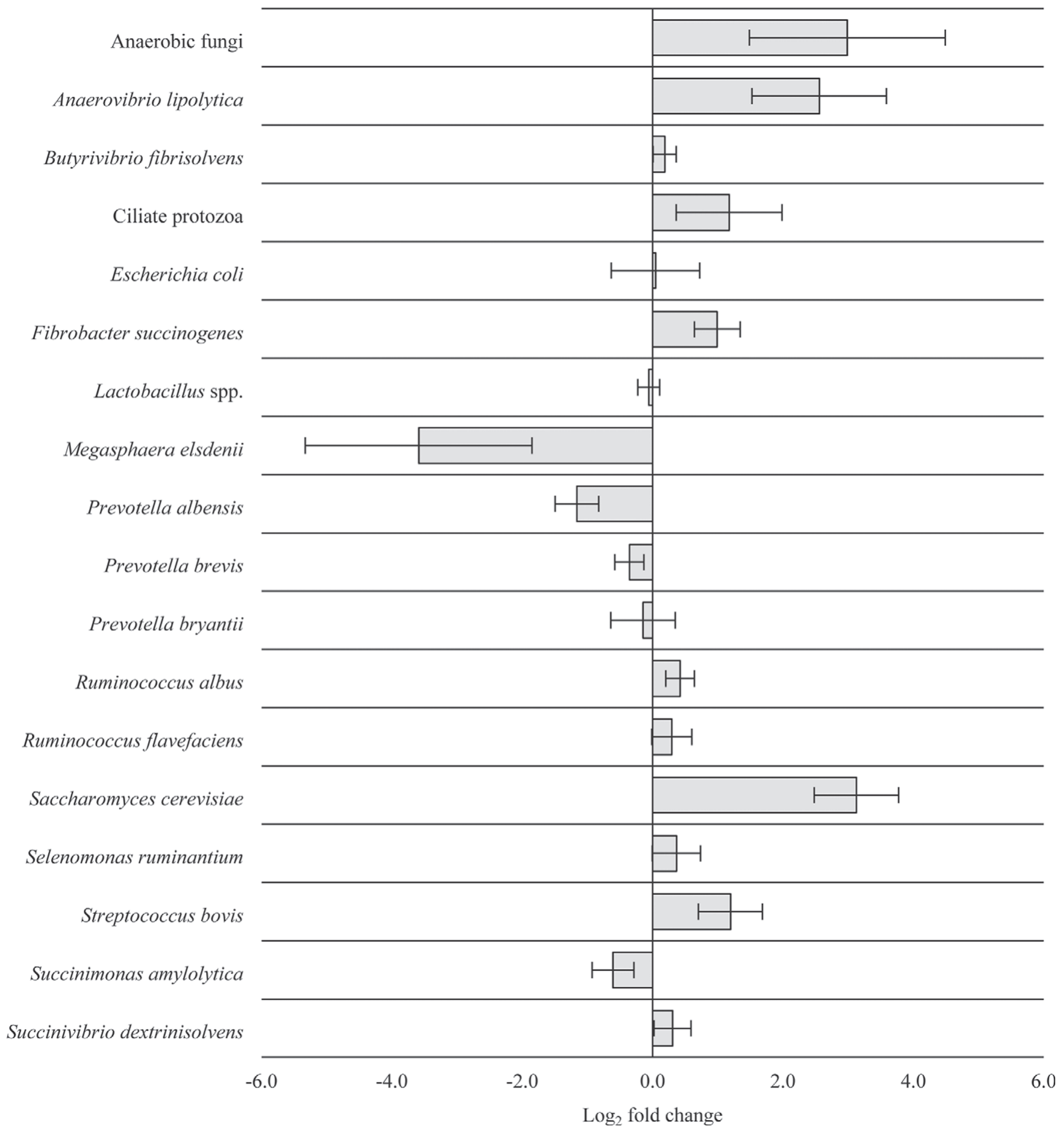

Figure 5. Changes $\left(\log _{2}\right)$ in ruminal microbes (stated at the y-axis) comparing cows supplemented with control (carrier only; $\left.\mathrm{n}=8\right)$ with cows receiving Saccharomyces cerevisiae $\left(8 \times 10^{10} \mathrm{cfu} /\right.$ head per day; $\left.\mathrm{n}=7\right)$ during high-grain feeding (samples collected on $\mathrm{d}$ 73). Error bars represent SE.

the modes of action of ADSC, being improved fiber degradation and reduced lactate within the rumen. However, our results lend support only for improved fiber degradation.
Additionally, $\operatorname{ADSC}\left(4 \times 10^{10} \mathrm{cfu} /\right.$ head per day $)$ was reported to enhance the numbers of ciliate protozoa within the rumen of sheep (Brossard et al., 2006). Ciliate protozoa can compete with amylolytic bacteria on 
substrate (starch), digest it slower, and produce VFA rather than lactate as an end product (Williams and Coleman, 1997). Therefore, it was suggested that ADSC may improve ruminal $\mathrm{pH}$ by enhancing the numbers of ciliate protozoa (Chaucheyras-Durand et al., 2008). Our results (Figure 5) showed no effect of ADSC on ciliate protozoa abundance.

Furthermore, in the current study, cows supplemented with ADSC had 2.2-fold reduction in P. albensis, which is a gram-negative bacterium predominant during SARA (Khafipour et al., 2009). Prevotella spp. are suggested to be an important source of LPS responsible for inflammation within the rumen and likely the incidence of lameness (Plaizier et al., 2008). Therefore, a reduction in gram-negative bacteria with ADSC supplementation is expected to have positive consequences on cow health. The ADSC supplementation increased S. bovis, a lactate-producing bacterium in spite of the increase in ruminal $\mathrm{pH}$. Cows supplemented with ADSC had greater intake and, thus, greater starch intake. Therefore, it is speculated that this increase was a reflection of substrate availability.

More studies are needed to evaluate the effect of live yeast on rumen ecology and function, taking into consideration several factors that might interact with yeast, such as diet type, stage of lactation, and environment. Differences between strains and dosage should also be considered. The interaction between yeast and the host animal should be examined, namely during the onset of SARA. Recent studies have suggested that variation among animals during SARA may be explained by differences in ruminal epithelium structure (Steele et al., 2011), gene expression related to FA metabolism (Penner et al., 2009; Steele et al., 2012), or innate immune responses (Dionissopoulos et al., 2014). In conclusion, our results demonstrated that supplementing lactating dairy cows with a live yeast product can reverse the progress of SARA and its associated negative effect on DMI and milk production. The study suggested a positive effect of live yeast on fiber-degrading bacteria as the mode of action, but provided no evidence of enhanced lactate utilization within the rumen.

\section{ACKNOWLEDGMENTS}

The authors thank Laura Wright and the staff of the Ponsonby Dairy Research Centre (University of Guelph, Guelph, ON, Canada) for their technical assistance; AB Vista (Marlborough, UK)/AB Mauri (Peterborough, UK), Natural Science \& Engineering Research Council of Canada (Ottawa, ON, Canada), and Ontario Ministry of Agriculture and Food (Guelph, ON, Canada) for their financial support.

\section{REFERENCES}

Al-Ibrahim, R. M., V. P. Gath, D. P. Campion, C. McCarney, P. Duffy, and F. J. Mulligan. 2012. The effect of abrupt or gradual introduction to pasture after calving and supplementation with Saccharomyces cerevisiae (strain 1026) on ruminal pH and fermentation in early lactation dairy cows. Anim. Feed Sci. Technol. 178:40-47.

Allen, M. S. 1997. Relationship between fermentation acid production in the rumen and the requirement for physically effective fiber. J. Dairy Sci. 80:1447-1462.

AlZahal, O., E. Kebreab, J. France, and B. W. McBride. 2007a. A mathematical approach to predicting biological values from ruminal pH measurements. J. Dairy Sci. 90:3777-3785.

AlZahal, O., M. M. Or-Rashid, S. L. Greenwood, M. S. Douglas, and B. W. McBride. 2009. The effect of dietary fiber level on milk fat concentration and fatty acid profile of cows fed diets containing low levels of polyunsaturated fatty acids. J. Dairy Sci. 92:1108-1116.

AlZahal, O., M. M. Or-Rashid, S. L. Greenwood, and B. W. McBride. 2010. Effect of subacute ruminal acidosis on milk fat concentration, yield and fatty acid profile of dairy cows receiving soybean oil. J. Dairy Res. 77:376-384.

AlZahal, O., B. Rustomo, N. E. Odongo, T. F. Duffield, and B. W. McBride. 2007b. Technical note: A system for continuous recording of ruminal $\mathrm{pH}$ in cattle. J. Anim. Sci. 85:213-217.

AOAC International. 1996. Official Methods of Analysis. 16th ed. AOAC International, Arlington, VA.

Brossard, L., F. Chaucheyras-Durand, B. Michalet-Doreau, and C. Martin. 2006. Dose effect of live yeasts on rumen microbial communities and fermentations during butyric latent acidosis in sheep: New type of interaction. Anim. Sci. 82:829-836.

Callaway, E. S., and S. A. Martin. 1997. Effects of a Saccharomyces cerevisiae culture on ruminal bacteria that utilize lactate and digest cellulose. J. Dairy Sci. 80:2035-2044.

Carro, M. D., P. Lebzien, and K. Rohr. 1992. Influence of yeast culture on the in vitro fermentation (Rusitec) of diets containing variable portions of concentrates. Anim. Feed Sci. Technol. 37:209-220.

Castillo-Lopez, E., P. J. Kononoff, and J. L. Miner. 2010. Short communication: Detection of yeast DNA in omasal digesta of dairy cows consuming dried distillers grains and solubles. J. Dairy Sci. 93:5926-5929.

CCAC (Canadian Council on Animal Care). 1993. Guide to the Care and Use of Experimental Animals. CCAC, Ottawa, ON, Canada.

Chaucheyras, F., G. Fonty, G. Bertin, and P. Gouet. 1995. Effects of live Saccharomyces cerevisiae cells on zoospore germination, growth, and cellulolytic activity of the rumen anaerobic fungus, Neocallimastix frontalis MCH3. Curr. Microbiol. 31:201-205.

Chaucheyras-Durand, F., N. D. Walker, and A. Bach. 2008. Effects of active dry yeasts on the rumen microbial ecosystem: Past, present and future. Anim. Feed Sci. Technol. 145:5-26.

Chiquette, J. 1995. Saccharomyces cerevisiae and Aspergillus oryzae, used alone or in combination, as a feed supplement for beef and dairy cattle. Can. J. Anim. Sci. 75:405-415.

Chung, Y. H., N. D. Walker, S. M. McGinn, and K. A. Beauchemin. 2011. Differing effects of 2 active dried yeast (Saccharomyces cerevisiae) strains on ruminal acidosis and methane production in nonlactating dairy cows. J. Dairy Sci. 94:2431-2439.

Denman, S. E., and C. S. McSweeney. 2006. Development of a realtime PCR assay for monitoring anaerobic fungal and cellulolytic bacterial populations within the rumen. FEMS Microbiol. Ecol. 58:572-582.

Dionissopoulos, L., O. AlZahal, M. A. Steele, J. C. Matthews, and B. W. McBride. 2014. Transcriptomic changes in ruminal tissue induced by the periparturient transition in dairy cows. Am. J. Anim. Vet. Sci. 9:36-45.

Dionissopoulos, L., A. Laarman, O. AlZahal, S. Greenwood, M. A. Steele, J. C. Plaizier, J. C. Matthews, and B. W. McBride. 2013 Butyrate-mediated genomic changes involved in non-specific hose defenses, matrix remodeling and the immune response in the rumen epithelium of cows affiliated with subacute ruminal acidosis. Am. J. Anim. Vet. Sci. 8:8-27. 
Fonty, G., and F. Chaucheyras-Durand. 2006. Effects and modes of action of live yeasts in the rumen. Biologia (Bratisl.) 61:741-750.

Giger-Reverdin, S., G. Bertin, J. Tessier, and D. Sauvant. 2004. Effet d'une levure (Saccharomyces Cerevisiae CBS 493.94) sur le métabolisme ruminal de la chèvre laitière. Page 265 in 11èmes Rencontres autour des Recherches sur les Ruminants, Paris, France. Institut National de la Recherche Agronomique, Paris, France.

Hall, M. B. 2000. Starch gelatinization and hydrolysis method. Pages 29-38 in Neutral Detergent Soluble Carbohydrates, Nutritional Relevance and Analysis-A Laboratory Manual. Dept. Animal Science, Univ. Florida, Gainesville.

Khafipour, E., S. C. Li, J. C. Plaizier, and D. O. Krause. 2009. Rumen microbiome composition determined using two nutritional models of subacute ruminal acidosis. Appl. Environ. Microbiol. 75:7115-7124.

Klieve, A. V., D. Hennessy, D. Ouwerkerk, R. J. Forster, R. I. Mackie, and G. T. Attwood. 2003. Establishing populations of Megasphaera elsdenii YE 34 and Butyrivibrio fibrisolvens YE 44 in the rumen of cattle fed high grain diets. J. Appl. Microbiol. 95:621-630.

Kung, L., E. M. Kreck, R. S. Tung, A. O. Hession, A. C. Sheperd, M. A. Cohen, H. E. Swain, and J. A. Z. Leedle. 1997. Effects of a live yeast culture and enzymes on in vitro ruminal fermentation and milk production of dairy cows. J. Dairy Sci. 80:2045-2051.

Lan, Y., S. Xun, S. Tamminga, B. A. Williams, M. W. A. Verstegen, and G. Erdi. 2004. Real-time PCR detection of lactic acid bacteria in cecal contents of Eimeria tenella-infected broilers fed soybean oligosaccharides and soluble soybean polysaccharides. Poult. Sci. 83:1696-1702.

Licitra, G., T. M. Hernandez, and P. J. Van Soest. 1996. Standardization of procedures for nitrogen fractionation of ruminant feeds. Anim. Feed Sci. Technol. 57:347-358.

Littell, R. C., G. A. Milliken, W. W. Stroup, and R. D. Wolfinger. 1996. SAS System for Mixed Models. SAS Inst. Inc., Cary, NC.

Livak, K. J., and T. D. Schmittgen. 2001. Analysis of relative gene expression data using real-time quantitative PCR and the $2^{-\triangle \Delta C T}$ method. Methods 25:402-408.

Mertens, D. R. 1997. Creating a system for meeting the fiber requirements of dairy cows. J. Dairy Sci. 80:1463-1481.

Mutsvangwa, T., J. P. Walton, J. C. Plaizier, T. F. Duffield, R. Bagg, P. Dick, G. Vessie, and B. W. McBride. 2002. Effects of a monensin controlled-release capsule or premix on attenuation of subacute ruminal acidosis in dairy cows. J. Dairy Sci. 85:3454-3461.

Newbold, C. J. 1995. Microbial feed additives for ruminants. Pages 259-278 in Biotechnology in Animal Feeds and Animal Feeding. R. J. Wallace and A. Chesson, ed. VCH, Weinheim, Germany.

Nocek, J. E. 1997. Bovine acidosis: Implications on laminitis. J. Dairy Sci. 80:1005-1028.

NRC. 2001. Nutrient Requirements of Dairy Cattle. 7th rev. ed. National Academies Press, Washington, DC.

Oetzel, G. R. 2000. Clinical aspects of ruminal acidosis in dairy cattle. Pages 46-53 in Proc. 33rd Annu. Mtg. Am. Assoc. Bovine Pract., Rapid City, SD. American Association of Bovine Practitioners, Stillwater, OK.

Ozutsumi, Y., K. Tajima, A. Takenaka, and H. Itabashi. 2006. Realtime PCR detection of the effects of protozoa on rumen bacteria in cattle. Curr. Microbiol. 52:158-162.
Penner, G. B., J. R. Aschenbach, G. Gabel, R. Rackwitz, and M. Oba. 2009. Epithelial capacity for apical uptake of short chain fatty acids is a key determinant for intraruminal $\mathrm{pH}$ and the susceptibility to subacute ruminal acidosis in sheep. J. Nutr. 139:1714-1720.

Pinloche, E., N. McEwan, J. P. Marden, C. Bayourthe, E. Auclair, and C. J. Newbold. 2013. The effects of a probiotic yeast on the bacterial diversity and population structure in the rumen of cattle. PLoS ONE 8:e67824.

Plaizier, J. C., D. O. Krause, G. N. Gozho, and B. W. McBride. 2008. Subacute ruminal acidosis in dairy cows: The physiological causes, incidence and consequences. Vet. J. 176:21-31.

SAS Institute. 2011. SAS/STAT User's Guide. Release 9.3. SAS Inst. Inc., Cary, NC.

Soder, K. J., and L. A. Holden. 1999. Dry matter intake and milk yield and composition of cows fed yeast prepartum and postpartum. J. Dairy Sci. 82:605-610.

Steele, M. A., J. Croom, M. Kahler, O. AlZahal, S. E. Hook, K. Plaizier, and B. W. McBride. 2011. Bovine rumen epithelium undergoes rapid structural adaptations during grain-induced subacute ruminal acidosis. Am. J. Physiol. Regul. Integr. Comp. Physiol. 300:R1515-R1523.

Steele, M. A., L. Dionissopoulos, O. AlZahal, J. Doelman, and B. W. McBride. 2012. Rumen epithelial adaptation to ruminal acidosis in lactating cattle involves the coordinated expression of insulin-like growth factor-binding proteins and a cholesterolgenic enzyme. J. Dairy Sci. 95:318-327.

Stella, A. V., R. Paratte, L. Valnegri, G. Cigalino, G. Soncini, E. Chevaux, V. Dell'Orto, and G. Savoini. 2007. Effect of administration of live Saccharomyces cerevisiae on milk production, milk composition, blood metabolites, and faecal flora in early lactating dairy goats. Small Rumin. Res. 67:7-13.

Stevenson, D. M., and P. J. Weimer. 2007. Dominance of Prevotella and low abundance of classical ruminal bacterial species in the bovine rumen revealed by relative quantification real-time PCR. Appl. Microbiol. Biotechnol. 75:165-174.

Swartz, D. L., L. D. Muller, G. W. Rogers, and G. A. Varga. 1994. Effect of yeast cultures on performance of lactating dairy cows: A field study. J. Dairy Sci. 77:3073-3080.

Sylvester, J. T., S. K. R. Karnati, Z. T. Yu, M. Morrison, and J. L. Firkins. 2004. Development of an assay to quantify rumen ciliate protozoal biomass in cows using real-time PCR. J. Nutr. 134:3378-3384.

Williams, A. G., and G. S. Coleman. 1997. The rumen protozoa. Pages 73-139 in The Rumen Microbial Ecosystem. 2nd ed. P. N. Hobson and C. S. Stewart, ed. Chapman \& Hall, London, UK.

Wohlt, J. E., A. D. Finkelstein, and C. H. Chung. 1991. Yeast culture to improve intake, nutrient digestibility, and performance by dairycattle during early lactation. J. Dairy Sci. 74:1395-1400.

$\mathrm{Yu}, \mathrm{Z}$., and M. Morrison. 2004. Improved extraction of PCR-quality community DNA from digesta and fecal samples. Biotechniques $36: 808-812$. 